\title{
Evaluation and Validation of Rice (Oryza sativa L.) Genotypes for Tissue Culture Response from Mature Embryos
}

\author{
Aafreen Sakina ${ }^{1}$, Zahoor A. Rather ${ }^{2}$, Saba Mir ${ }^{1}$, Sajad M. Zargar ${ }^{1}$, Imtiyaz Murtaza ${ }^{3}$, \\ Nagina Nazir ${ }^{4}$, Ambreena Din ${ }^{2}$ and Asif B. Shikari ${ }^{*}$
}

${ }^{1}$ Division of Plant Biotechnology, Sher-e-Kashmir University of Agricultural Sciences and

Technology of Kashmir (SKUAST-K), Shalimar, J\&K, 190025, India

${ }^{2}$ Division of Floriculture \& Landscaping, Sher-e-Kashmir University of Agricultural Sciences and Technology of Kashmir (SKUAST-K), Shalimar, J\&K, 190025, India

${ }^{3}$ Division of Basic Sciences and Humanities, Sher-e-Kashmir University of Agricultural

Sciences and Technology of Kashmir (SKUAST-K), Shalimar, J\&K, 190025, India

${ }^{4}$ Division of Agricultural Statistics, Sher-e-Kashmir University of Agricultural Sciences and

Technology of Kashmir (SKUAST-K), Shalimar, J\&K, 190025, India

\section{*Corresponding author}

\section{A B S T R A C T}

\begin{tabular}{|c|}
\hline Keywords \\
\hline $\begin{array}{l}\text { Rice, Tissue culture } \\
\text { embryo, Genotypes, } \\
\text { Regeneration }\end{array}$ \\
\hline Article Info \\
\hline $\begin{array}{l}\text { Accepted: } \\
20 \text { November } 2019 \\
\text { Available Online: } \\
10 \text { December } 2019\end{array}$ \\
\hline
\end{tabular}

The biotechnological intervention to enhance crop productivity via genetic transformation mainly depends upon an efficient regeneration protocol. Japonica, Indica and Basmati varieties of rice vary highly in their regeneration capabilities. Establishment of a highly efficient regeneration system for mature embryos in rice will enable transformation of foreign genes in rice. In this study, 12 genotypes of rice representing japonica, indica and basmati varieties were assessed for their calli and green plant regeneration frequencies. The mature seeds of the genotypes were inoculated on MS media supplemented with auxin (2,4-D @ $2.5 \mathrm{mg} / \mathrm{l})$, cytokinin (kinetin@ 0.5mg/l) and 3\% sucrose. They exhibited variable calli induction and green plant regeneration frequencies. Calli regeneration frequency ranged from 100\% - 20\%, highest being in GS-88, Kamad and PS-3 (100\%) and lowest in Kohsar (20\%). Highest regeneration frequency was obtained in K-332 and Kamad. Among all the varieties K-332, GS-88 and Kamad performed well in respect of callus induction and green plant regeneration. The plants were successfully acclimatized and transferred to pots.

\section{Introduction}

"Rice (Oryza sativa L.) is a source of food to over three and a half-billion people and in Asia alone, around two billion people obtain more than $50 \%$ of their dietary calories from rice and rice products (Caicedo et al., 2007)".
Globally the crop is grown over 167.24 mha area with the production of 769.65 million tonnes (http://www.fao.org/faostat/, 2017). Genetic and molecular make-up of rice is under active investigation and it is considered as a model monocot system due to its relatively small genome size of $389 \mathrm{Mb}$, ease 
of transformation, well known genetics (Sahi et al., 2006), availability of a dense physical map and molecular markers (Wu et al., 2002), full-genome transcription profiling using high density oligonucleotide tiling microarrays ( $\mathrm{Li}$ et al., 2006) together with its complete genome sequence (Sasaki et al., 2005).

Since the landmark breakthrough of sequencing of rice genome, considerable progress has been achieved in the area of genetic engineering, functional genomics and annotation of genes of agronomic importance (Shimamoto and Kyozuka, 2002; Bajaj and Mohanty, 2005; Ge et al., 2006). Validation and standardization of in vitro tissue culture technique is a prerequisite for working on such advance areas pertaining to plant transformation (Jan et al., 2001) and functional genomics.

Diverse rice germplasm of temperate origin is being maintained at MRCFC, Khudwani, SKUAST-Kashmir. Mostly the germplasm has been characterized for cold tolerance, earliness, agronomic traits and for resistance to biotic stresses (Najeeb et al., 2015).

Some of the important rice accessions were selected for studying their response and amenability to tissue culture.

Tissue culture response is usually characterized by high genotype to protocol interaction (Ge et al., 2006) and is affected by the number of factors such as composition of basal media, explant, culture conditions, combinations of plant growth regulators (PGRs) and the genotype (Azria and Bhalla, 2000). Therefore, it becomes necessary to standardize a procedure on a set of genotypes with respect to standard media conditions and procedures. The objective of our study was to evaluate the genotypic variation in callus formation and regeneration capacity of rice genotypes under tissue culture.

\section{Materials and Methods}

\section{Plant material}

Pure seeds of 12 experimental genotypes procured from MRCFC, Khudwani, SKUAST- Kashmir were used as source of mature embryos for callus induction and plant regeneration (Table 1). The study was conducted at Plant Tissue Culture Lab, Faculty of Horticulture, SKUAST- Kashmir, J\&K, India during the years 2018 and 2019.

\section{Seed sterilization}

Mature healthy seeds of all the genotypes were carefully dehusked with a sharp scalpel, disinfected through washing with water using few drops of Tween 20 for 5 minutes.

Seeds were surface sterilized with mercuric chloride $(0.1 \% \mathrm{w} / \mathrm{v})$ for $10 \mathrm{mins}$ followed by 5 washes with autoclaved distilled water under the laminar flow hood.

\section{Callus induction media}

Murashige and Skoog (1962) (MS) media was used for callus induction. In this study, MS media supplemented with 2,4-D @ $2.5 \mathrm{mg} / \mathrm{l}$ and kinetin@0.5mg/l which proved as a best combination in an earlier study conducted by Wani et al., (2011) was used. Sucrose (3\%) was used as a sole carbon source. $\mathrm{pH}$ of media was adjusted at 5.8 by adding $1.0 \mathrm{~N} \mathrm{HCl}$ with the help of $\mathrm{pH}$ meter. The media was solidified with $0.8 \%$ agar and autoclaved at $121^{\circ} \mathrm{C}$ for 15 minutes at $15 \mathrm{psi}$. Media was poured in the petriplates under laminar air flow. Sterilized seeds were placed on the callus induction media and the petriplates were incubated in culture room with 16 hours of light and 8 hours of dark cycle at $25 \pm 1{ }^{\circ} \mathrm{C}$. Incubation was continued till emergence and growth of calli for a period of 2-3 weeks in culture room. 


\section{Regeneration and hardening media}

Regeneration media contained full strength MS, $3 \%$ sucrose and growth hormones BAP (2 $\mathrm{mg} / \mathrm{l})$ and NAA $(0.5 \mathrm{mg} / \mathrm{l})$ and Kinetin $(0.5$ $\mathrm{mg} / \mathrm{l}) . \mathrm{pH}$ of the media was adjusted to 5.7 and solidified with $8 \mathrm{~g} / \mathrm{l}$ agar. Media was autoclaved for $20 \mathrm{~min}$ at $121^{\circ} \mathrm{C}$.Calli induced from seeds were transferred to regeneration media. After calli regeneration plantlets were transferred to plastic cups containing autoclaved pre-soaked vermiculite and perlite medium, in the ratio of 1:1 inside the growth chamber.

$80 \% \mathrm{RH}$ and $28^{\circ} \mathrm{C}$ temperature was maintained inside the growth chamber. After hardening for 15 days in growth chamber, plants were transferred to the soil in the mud pots and were kept in green house and maintained at $30^{\circ} \mathrm{C}$ with $70 \%$ relative humidity for the period of 30 days and later transferred to field in open air conditions.

\section{Data analysis and statistics}

The experiment was laid in Complete Randomized Design (Gomez and Gomez, 1984).Each of the 12 genotypes was represented by 14 seeds per petri plate and such two plates per genotype (corresponding to two replications) comprised of one experimental unit.

Observations were recorded on callus induction and green plant regeneration at appropriate time. The Callus induction frequency (CIF) was obtained from the number of calli against the total number of explants inoculated. Similarly, the Green plantlet differentiation frequency (GPDF) was calculated on the number of green plantlet differentiation as percentage of the number of transferred calli. Analysis of variance was performed using NCSS Statistical Software (2019).

\section{Results and Discussion}

\section{Callus initiation}

Sterilized dehusked seeds of 12 genotypes were inoculated on MS media supplemented with growth regulators, 2,4-D and Kinetin to estimate the differential response of genotypes towards tissue culture. After placing the seeds on MS media, seeds started germinating in a week's time and scutellum region of seeds swelled. Embryonic calli, light yellow and granular in appearance, started emerging from the swollen junction between radicle and mesocotyl in all the 14 genotypes. Callus induction was established after two weeks period. The genotypes depicted varied response towards callus induction and regeneration potential as evident from results based analysis of variance (Table 1). Highly significant mean squares were noted for parameters which define tissue culture response over rice genotypes. Differential genotype response for callus induction has been reported by Diawuoh et al., (2016).

Success intissue culture mainly depends upon the source of explant, genotype and medium Growth regulator 2,4-D is the most suitable Auxin for callus induction.

Different concentrations of 2,4-D havebeen assessed by different workers to find the optimal working concentration that gives best callus induction. A study conducted by Vennapusa et al., (2015) showed that highest callus frequency was obtained on LS media containing $2.5 \mathrm{mg} / \mathrm{L} 2,4-\mathrm{D}$. Diawuoh et al., (2016) also worked with dehusked rice and reported that 2,4-D is the best auxin for callus induction.

The highest callus induction was observed in rice germplasm line GS-88, aromatic landrace Kamad and fine grained aromatic variety, Pusa Sugandh 3. 
Table.1 Analysis of variance for traits related to tissue culture response across a set of temperate rice genotypes

\begin{tabular}{|l|l|l|l|l|}
\hline Source of Variation & d.f. & \multicolumn{2}{|c|}{ Mean squares } & Probability \\
\hline Genotypes & & Callus Induction (\%) & Regeneration (\%) & \\
\hline Error & 11 & 17.58 & 21.37 & 0.000005 \\
\hline
\end{tabular}

Table.2 Callus induction and regeneration response of genotypes

\begin{tabular}{|l|l|l|l|}
\hline Genotypes & Characteristic features & $\begin{array}{l}\text { Callus } \\
\text { Induction (\%) }\end{array}$ & $\begin{array}{l}\text { Regeneration } \\
(\%)\end{array}$ \\
\hline Madew-2 & Japonica red rice & 71.4 & 30 \\
\hline SKUA-420 & Non- aromatic basmati & 93.3 & 70 \\
\hline GS-19 & Japonica aromatic rice & 84.6 & 90 \\
\hline Jehlum & Indica variety for high altitudes $(1600 \mathrm{msl})$ & 25.0 & 5 \\
\hline Zeera Rice & Short grained indica & 68.0 & 50 \\
\hline Tangdar Zag & Japonica red rice & 80.0 & 30 \\
\hline MB 4-40 & Pyramided MushkBudji & 64.3 & 95 \\
\hline K-332 & Japonica variety for high altitudes $(2000 \mathrm{msl})$ & 94.4 & 100 \\
\hline Pusa Sugandh 3 & Fine grained aromatic & 100.0 & 80 \\
\hline Kohsar & Japonica variety for high altitudes $(2000 \mathrm{msl})$ & 20.0 & 20 \\
\hline Kamad & Short grained aromatic landrace & 100.0 & 100 \\
\hline GS-88 & Japonica & 100.0 & 95 \\
\hline
\end{tabular}

Fig.1 Percent callus induction and plant regeneration of 12 genotypes in MS media

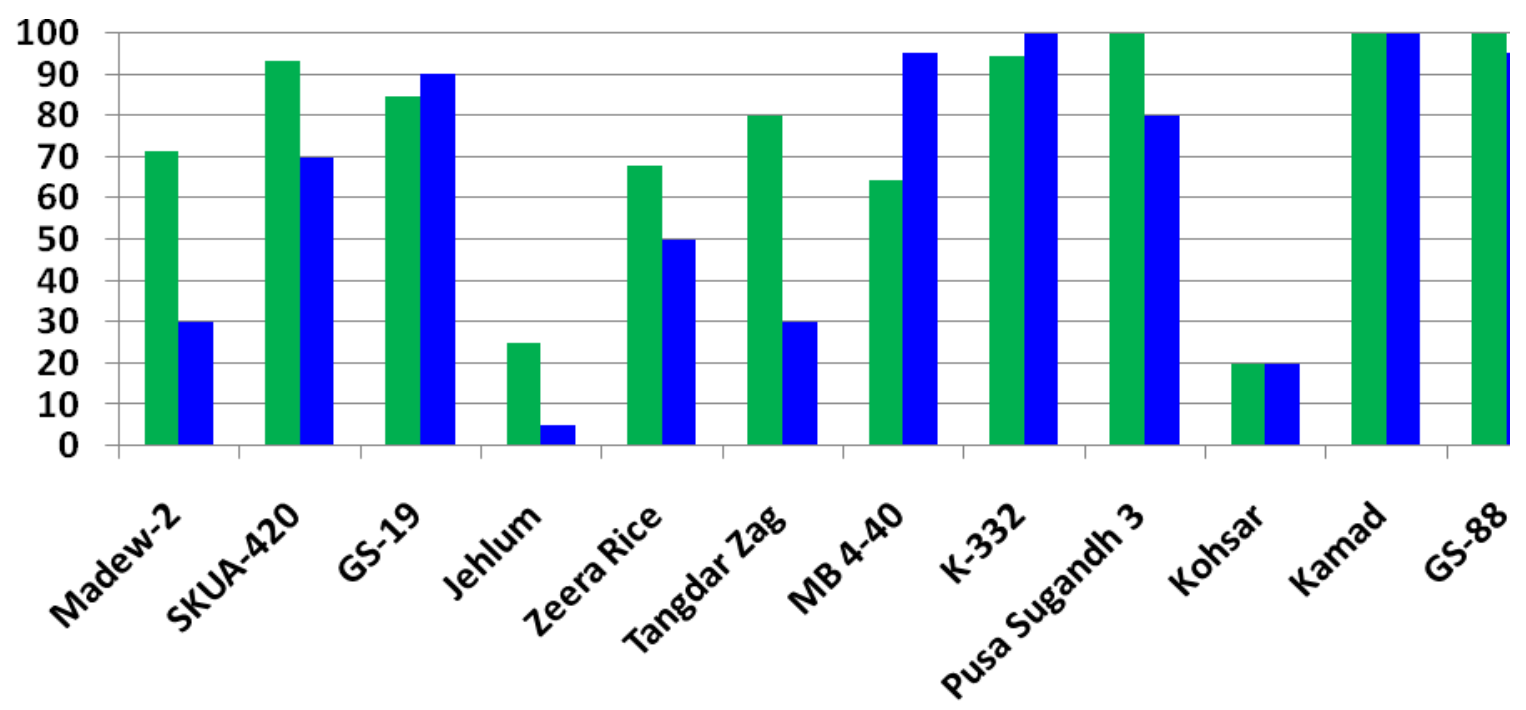

Calli induction (\%) $\quad$ Regeneration (\%) 
Fig.2 Seed explant tissue culture of rice genotypes
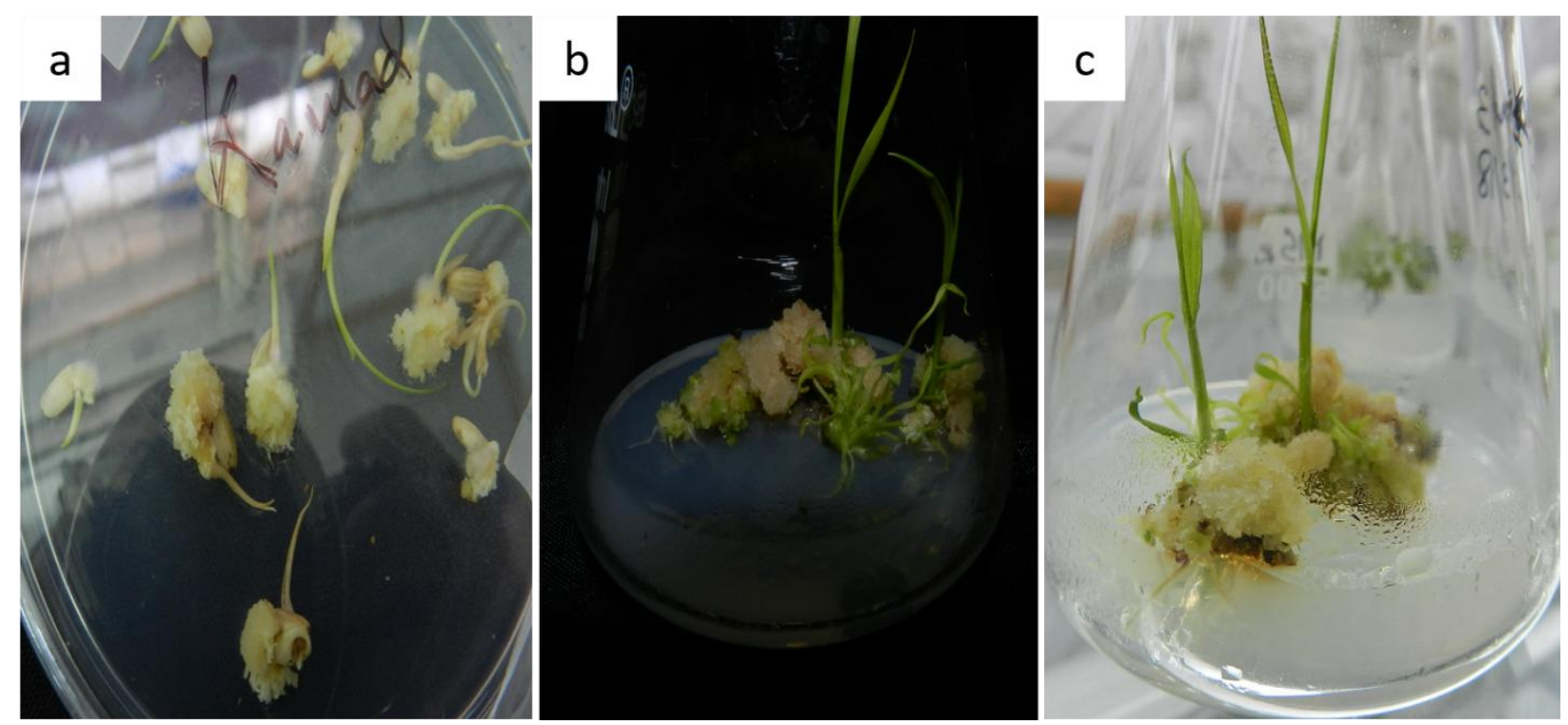

a: Calli induction; b \& c: green plant regeneration

Callus induction potential varied across genotypes, K-332 (94.4\%), SK-420 (93.3\%), GS-19 (84.6\%), Tangdar Zag (80\%), Madew$2(71 \%)$, Zeera rice (68\%), MB 4-40 (64.3\%), Jehlum (25\%) and was lowest for Kohsar (20\%) (Table 2 and Figure 1).

\section{Shoot regeneration}

Among the various genotypes, the enhanced regeneration potential was observed in K-332 and Kamad followed by MB 4-40. Jehlum and Kohsar had lowest regeneration potential (Figure 1 and 2). Variable regeneration potential was observed by Biswas et al., (2007) among the genotypes inoculated on regeneration media which is in line with the present study and emphasizes that regeneration is genetically controlled trait and may show differential behaviour.

\section{Acclimatization}

Around 95\% of the in-vitro developed plants survived the hardening process both in green house as well as the net house conditions. Regenerants were transferred to field where they exhibited normal growth and development and produced viable seeds.

Overall, the genotypes K-332, GS-88 and Kamad performed better as regards callus induction and green plant regeneration followed by Pusa Sugandh 3, MB 4-40 and GS-19. These genotypes can easily be utilized in transformation studies due to their excellent calli induction and green plant regeneration rates. Moreover, the study helped to validate the given media composition on set of germplasm adapted to temperate high altitude climate.

\section{References}

Azria D, Bahalla PL 2000 Plant regeneration from mature embryo-derived callus of Australian rice (Oryza sativa L.) varieties. Australian Journal of Agriculture Research 51 (2), 305-312

Bajaj S, Mohanty A. 2005. Recent advances in rice biotechnology - towards genetically superior transgenic rice. Plant Biotechnol J 3:275 - 307 .

Bano S, Jabeen M, Rahim F and Ilahi I.2005. 
Callus induction and regeneration in seed explants of rice (Oryza sativa cv. swat-ii). Pak. J. Bot., 37(3): 829-836.

Biswas, A and Mandal AB., 2007. Plant regeneration in different genotypes of indica rice. Indian journal of biotechnology. 6:532-540.

Caicedo, A.L., Williamson, S.H., Hernandez, R.D., Boyko, A., Fledel, Alon. A., York T.L et al., (2007). Genome-Wide Patterns of Nucleotide Polymorphism in Domesticated Rice. PloS Genetics. 3(9):1745-56.

Diawuoh, RG, Klu, G, Amoatey H., Kusi-Adjei R., Quartey EK. 2016. Callus Induction and Plant Regeneration from Dehusked Mature Seeds of Three Accessions of African Rice (Oryza glaberrima Steud.). Journal of Biology, Agriculture and Healthcare. 6(18)

FAOSTAT. 2017. http://www.fao.org/faostat/ en/\#data/QC/visualize.Production/ Yield quantities of Rice, paddy in World + (Total) $1994-2017$.

Ge X, Chu Z, Lin Y, Wang S. 2006. A tissue culture system for different germplasms of indica rice. Plant Cell Rep 25:392 402.

Gomez, KA and Gomez, AA. 1984. Statistical procedures for agricultural research (2 ed.). John wiley and sons, NewYork, 680p.

Jan A, Hassan QM, Fatima T and Hasnain T. 2001. Tissue Culture response of Local Varieties of Rice (Oryza sativa L.) of NWFP. OnLine Journal of Biological Sciences 1 (5): 387-390.

Kumar V, Shriram V, Jawali N and Shitole MG. 2007. Differential response of indica rice genotypes to $\mathrm{NaCl}$ stress in relation to physiological and biochemical parameters. Archives of Agronomy and Soil Science 53(5): 581 - 592.

Li L, Wang X, Stolc V, Li X, Zhang D, Su N, Tongprasit W, Li S, Chang Z, Wang J, Deng XW. 2006. Genome-wide transcription analyses in rice using tiling microarrays. Nature Genet 38:124 - 129.

Murashige, T. and F. Skoog. 1962. A revised medium for rapid growth and bioassay with tobacco tissue culture. Physiol. Plant., 15: 473-497.

Najeeb, S., Shikari, A.B. and Parray, G. A. (2015). Status Paper on Rice in Jammu and Kashmir. http://www.rkmp.co.in.

NCSS 2019 Statistical Software (2019). NCSS, LLC. Kaysville, Utah, USA, ncss.com/software/ncss.

Sahi C, Singh A, Kumar K, Blumwald E, Grover A. 2006. Salt stress response in rice: Genetics, molecular biology and comparative genomics. Funct Integr Genomics 6:263 - 284.

Sasaki T, Matsumoto T, Antonio BA, Nagamura Y. 2005. From mapping to sequencing, post-sequencing and beyond. Plant Cell Physiol 46:3 - 13.

Shimamoto K, Kyozuka J. 2002. Rice as a model for comparative genomics of plants. Annu Rev Plant Biol 53:399-419.

Vennapusa AR, Vemanna RS, Reddy B. H., Babitha KC, Kiranmai K, Nareshkumar A, Sudhakar C. 2015. An Efficient Callus Induction and Regeneration Protocol for a Drought Tolerant Rice Indica Genotype AC39020. Journal of Plant Sciences. 3(5), 248-254.

Wani SH., Silva JT., Sanghera GS., Haribhushan A., Singh NB., Gosal SS., 2011. Regeneration protocol for whole plants from embryogenic callus of commercial rice (Oryza sativa L.,) variety $P R$ 116. International journal of plant developmental biology. 5(1), 63-66.

Wu J, Maehara T, Shimokawa T, Yamamoto S, Harada C, Takazaki Y, Ono N, Mukai Y, Koike K, Yazaki J, Fujii F, Shomura A, Ando T, Kono I, Waki K, Yamamoto K, Yano M, Matsumoto T, Sasaki T. 2002. A comprehensive rice transcript map containing 6591 expressed sequence tag sites. Plant Cell 14: 525-535. 


\section{How to cite this article:}

Aafreen Sakina, Zahoor A. Rather, Saba Mir, Sajad M. Zargar, Imtiyaz Murtaza, Nagina Nazir, Ambreena Din and Asif B. Shikari. 2019. Evaluation and Validation of Rice (Oryza sativa L.) Genotypes for Tissue Culture Response from Mature Embryos. Int.J.Curr.Microbiol.App.Sci. 8(12): 2647-2653. doi: https://doi.org/10.20546/ijcmas.2019.812.309 